\title{
The Students' Motivation in Studying and Mastering a Profession in Coal Region Universities
}

\author{
Anna Resenchuk $^{1}$, and Nina Tunyova ${ }^{1, *}$ \\ ${ }^{1}$ Kemerovo State University, Institute of Philology, Foreign Languages and Media communications, \\ Department of Foreign Languages, 650000, 6 Krasnaya st., Kemerovo, Russia
}

\begin{abstract}
This paper discusses the approach to teach professional vocabulary and motivation to study to mining students with the emphasis on career guidance work and online technologies which can help enhance learning activities. They may include web services or applications used for creating activities and engage students to learning environment. The paper deals with integration into the educational process such web-services as Learning Apps, H5P, Factile, aimed students to build and enlarge professional vocabulary necessary to read and analyze scientific articles, to operate it in future professional activity while communicating with foreign colleagues. The results of diagnostic tool (questionnaire) allow us to work with communicative, personal, behavioral and professional competence of the students. The article notes that high professional interest and acquired knowledge and skills will make the students able to work successfully in the mining industry sharing experience and cooperating with international partners. Kuzbass (Kemerovo region) is one of the largest coal deposits in the world, located in the south of Western Siberia. Region has significant experience in training compatriot specialists and international students in geology, mining industry, ecology and nature management. Future highly qualified specialists should not only master the production process, but also be able to share experience and communicate with foreign colleagues.
\end{abstract}

\section{Introduction}

Increasing international cooperation in coal industry requires a future specialist an active use of foreign language. A great number of studies in coal mining are conducted and published by foreign scientists. A highly qualified specialist needs to learn how to work with English professional vocabulary to read the papers describing the results of experimental studies. The Scopus and WoS articles in the field of mining are scientific publications describing the results of experimental studies and formatted according to the technical requirements of the database journals. The text of the paper is presented in a strict, scientific style, coherently and logically. Forms, meanings and usages are involved in a vocabulary knowing [1]. Teaching professional vocabulary to the students in coal region universities is the key to understanding highly rated scientific articles (Scopus and WoS).

\footnotetext{
*Corresponding author: reseanna@yandex.ru
} 
Apart from Russian students, many international students from 24 countries are provided undergraduate and postgraduate education at the universities of Kuzbass [2]. Groups of students can be either monoethnic (Russian students) or multinational (the group includes students from Russia, Uzbekistan and Kyrgyzstan).

Meanwhile we are currently living in the digital era, which spreads through various areas, including education. And pandemic Covid 19 has only accelerated the usage of online learning tools and hybrid format of study. Classroom activities had been transformed into online learning format, including interactive worksheets, online tests, quizzes and polls, simulation games, etc. These alterations allowed students to increase learning motivation, ensure high learning outcomes. Nowadays some researchers start formulating concepts and teaching methods of scientific translation in e-learning environment [3]. It allows to organize and individualize studying process, create and develop self-education, which is highly topical due to classroom hours cut and self-study rise. This paper focuses on approach to teach professional vocabulary to mining students with the emphasis on career guidance work and online technologies to enhance learning activities.

Our aim was to build and enlarge professional vocabulary used in scientific papers through motivation increase and online learning activities. We understand the latter as web services or applications that can be used to create and engage students into learning. We supposed such activities could ensure high learning outcomes in the view of class-room hours reduction and rise of self-study work. Moreover, these activities can complement and support traditional learning methods. We developed a set of interactive tasks, quizzes (current, midterm and final), polls, created in LearningApps, H5P, Factile, Socrative, Google forms and integrated them in the ESP education process.

\section{Materials and methods}

The research on the students' motivation in studying and mastering a profession in coal region universities has been carried out since 2019 . To study students' motivation we used the following research methods: experiment connected with students' motivation reasons, questioning and interviewing (70 Bachelors of the Slavic language group, 16 Bachelors of the Turkic language group, 20 Master students of the Slavic language group of the Kemerovo State University), analyzing the obtained data.

"Motivating the learner to learn is pertinent to curriculum implementation. This is because motivation is an influential factor in the teaching-learning situations. The success of learning depends on whether or not the learners are motivated. Motivation drives learners in reaching learning goals. It is important to recognize the fact that motivating learning is a central element of good teaching" [4].

Motivating students to learn at the universities and mastering their profession is a topic of great concern for educators nowadays [5-7]. Students' motivation is a main element that is necessary for quality education. «Getting students to learn and sustaining their interest in what they are learning should be the sole objective of teachers in the classroom» [4]. To make an effort there must be a motive for a learner (desire and drive to achieve a certain goal).

Professional motivation determines the appropriateness of the professional path choice, the success of professional training, productivity of labor, and the degree of satisfaction with the results. An effective learning process is caused by at least two factors - the motivational sphere of specialists and the level of the cognitive sphere development.

The most important role of the professional motivation belongs to the positive attitude towards the profession in society and in family. Developing and implementing a system of professional motives in young specialists, such motivation features as a hierarchy of motives, polymotivation of labor behavior and compensatory relations between motives are considered. The professional motivation of young specialists is sometimes unstable, changes 
frequently and characterized by a certain dynamism. The degree of motivation dynamism depends on the nature of the person, his/her age, environment, specific life situation, family status.

In accordance with the requirements of the Federal State Educational Standard of Higher Education for the results of mastering professional educational programs, educational organizations must have a system of diagnostics, internal and external control, and assessment of new educational results.

The choice of a diagnostic tool (questionnaire) is determined by the compliance with the content of a certain criterion for the formation of communicative, personal, behavioral and professional competence. The competence-based approach in education is aimed at a reflexive assessment by students of their "possibilities" and "impossibilities", awareness of the boundaries of their competence, the acquisition of versatile experience, their simultaneous assimilation of the content component of education and personality development.

When creating this technique, the authors used a number of other well-known techniques. There are three scales in it: "Acquisition of knowledge" (the desire to acquire knowledge, curiosity); "Mastering a profession" (striving to acquire professional knowledge and form professionally important qualities); "Getting a diploma" (the desire to acquire a diploma in the formal assimilation of knowledge, the desire to find workarounds when passing exams and tests) [8]. To disguise the questionnaire, the author of the technique included a number of background statements, which are not further processed.

Instructions: Mark your agreement with a "+" or disagreement with the following statements.

1. The best classroom atmosphere is the atmosphere of free speech.

2. I usually work with a lot of stress.

3. I rarely have headaches after experiencing worries and troubles.

4. I am independently studying a number of subjects, in my opinion, necessary for my future profession.

5. Which of your inherent qualities do you value the most? Write your answer next to it.

6. I believe that life should be devoted to the chosen profession.

7. I take pleasure in dealing with difficult problems.

8. I don't see the point in most of the work we do at the university.

9. It gives me great satisfaction to tell my friends about my future profession.

10. I am a very average student, I will never be quite good, so there is no point in trying to become better.

11. I believe that in our time it is not necessary to have a higher education.

12. I am firmly convinced of the correct choice of profession.

13. Which of your inherent qualities would you like to get rid of? Write your answer next to it.

14. Whenever possible, I use auxiliary materials (notes, cheat sheets) for exams.

15.The most wonderful time of my life is my student years.

16. I have extremely restless and intermittent sleep.

17. I believe that to master the profession fully, all academic disciplines need to be studied equally deeply.

18. If possible, I would go to another university.

19. I usually take on the easier tasks first and leave the more difficult ones for later.

20. It was difficult for me to choose one of them when choosing a profession.

21. I can sleep well after any troubles.

22. I am firmly convinced that my profession gives me moral satisfaction and material wealth in life.

23. It seems to me that my friends are capable of learning better than me. 
24. It is very important for me to have a higher education diploma.

25. For some practical reasons, this is the most convenient university for me.

26. I have enough willpower to study without being reminded by the administration.

27. Life for me is almost always associated with extraordinary stress.

28. Exams should be taken with a minimum of effort.

29. There are many universities in which I could study with no less interest.

30. Which of your inherent qualities prevents you from learning the most? Write your answer next to it.

31. I am a very enthusiastic person, but all my hobbies are somehow connected with my future profession.

32. Worrying about an exam or a job that isn't completed on time often keeps me awake.

33. A high salary after graduation is not the main thing for me.

34. I need to be in good spirits to support the group's overall decision.

35. I had to go to university in order to take the desired position in society, to avoid serving in the army.

36. I am teaching material to become a professional, not for an exam.

37. My parents are good professionals and I want to be like them.

38. I need to have a higher education for promotion.

39. Which of your qualities helps you learn? Write your answer next to it.

40. It is very difficult for me to force myself to study properly disciplines that are not directly related to my future specialty.

41. I am very worried about possible failures.

42. Best of all, I do it when I am periodically stimulated, spurred on.

43. My choice of this university is final.

44. My friends have higher education and I don't want to be left behind.

45. To convince the group of something, I have to work very hard myself.

46. I am usually in a calm and good mood.

47. I am attracted by the convenience, cleanliness, ease of the future profession.

48. Before entering the university, I had been interested in this profession for a long time, I read a lot about it.

49. The profession that I am getting is the most important and promising one.

50. My knowledge of this profession was sufficient for a confident choice [8].

To enhance mastering profession motivation, we used some web-services (Learning Apps, H5P, Factile etc.) to create interactive tasks, worksheets, quizzes, tests. These services aimed to support word learning, review, and playing with language.

LearningApps is designed to support learning and teaching with interactive tasks and automatic check mode. Teachers can create their tasks filling out an appropriate template or search LearningApps database of already-created templates. The tasks can be shared with students or be embedded in any LMS or blog. Moreover, this service allows a teacher to trace learning progress of a student.

Templates can be in various formats: matching, grouping, putting in the correct order, completing, multiple-choice quiz, close test, word grid, the millionaire game, word puzzles etc. Matching terms task is shown in Figure 1. 


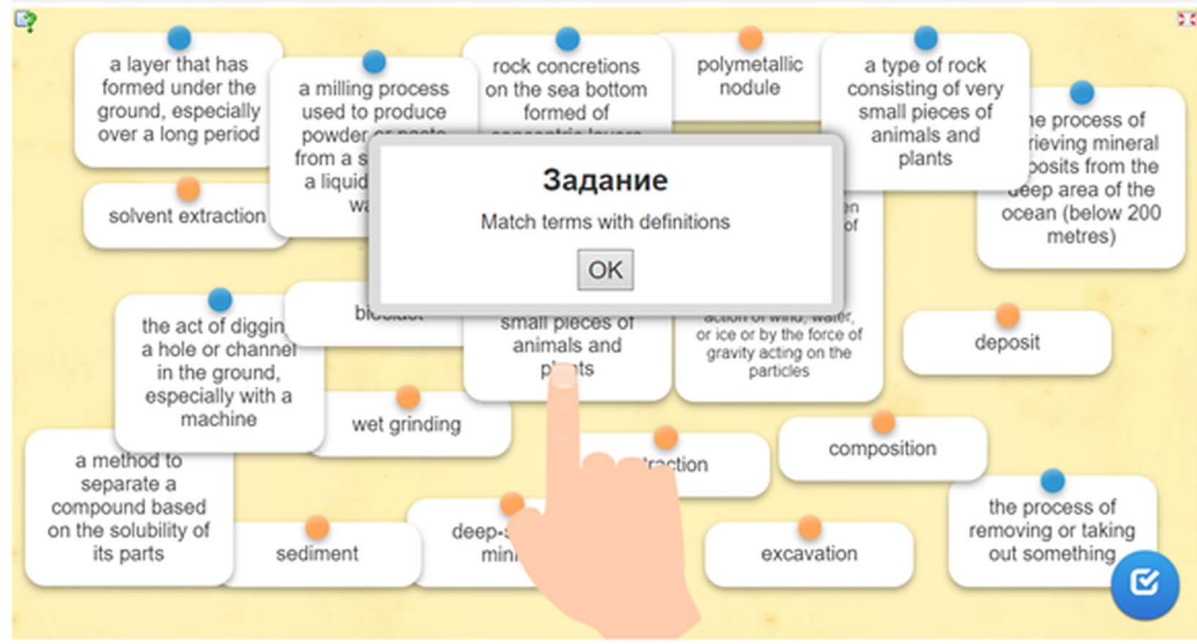

Fig. 1. Matching terms task for mining students.

Completing task is illustrated in Figure 2.

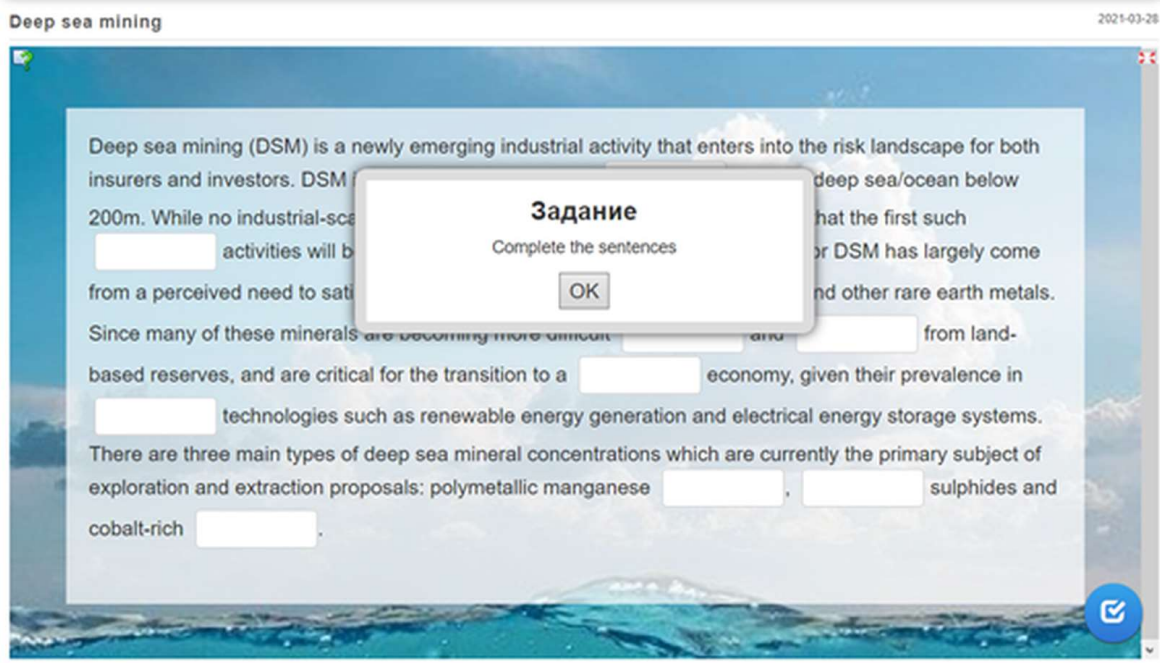

Fig. 2. Completing task for mining students.

Factile is a learning platform allowing teachers create engaging jeopardy-style quiz games. They can be used for the remote or offline study. Techers can assess both students' understanding of a new topic or review the latest concepts using simple friendly game board template. Teachers can create and share their games with students or search Factile database of already-created games. These jeopardy games can be a great option to complement lectures or topic studying. As a teacher can divide the board into different topics (parts of one topic) and use it as a discussion activity. Students can play individually or in teams and they can choose amazing avatars and nicknames. Revision game is illustrated in Figure 3. 


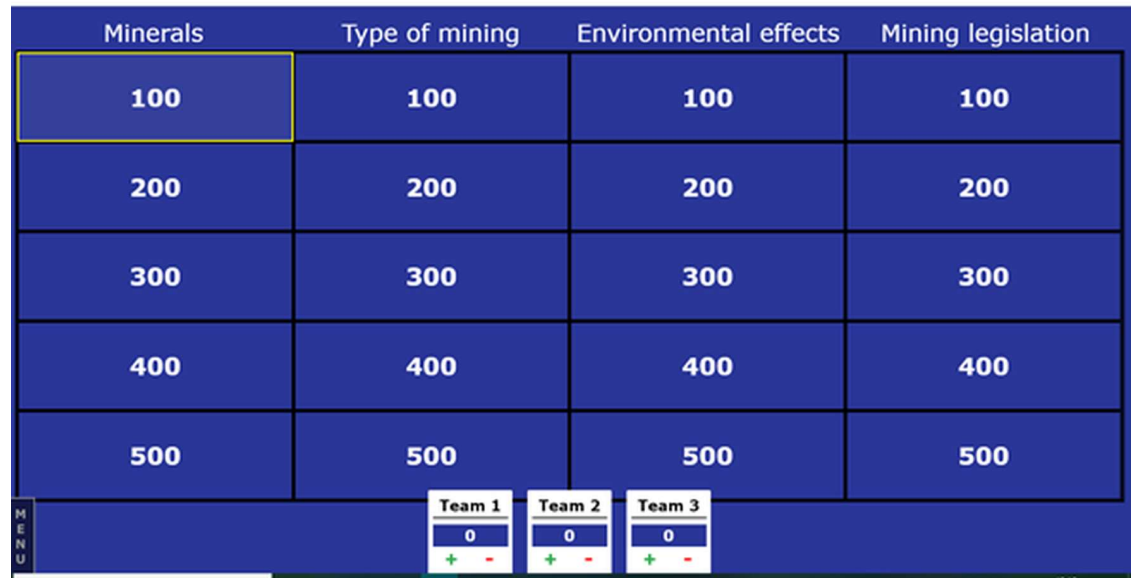

Fig. 3. Revision game for mining students.

Game content (questions and responses) are illustrated in Figure 4.

\begin{tabular}{|c|c|c|c|}
\hline \multicolumn{4}{|c|}{ Strom: goversoms Finet } \\
\hline Misoctabs & Iype of mixing & tenviroememed eftects & Miring Kegistation \\
\hline \multirow{2}{*}{ 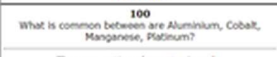 } & \multirow{2}{*}{ 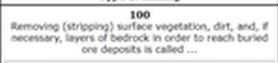 } & 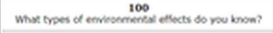 & motistse \\
\hline & & 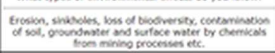 & Examperes speces nata \\
\hline \multirow{3}{*}{ 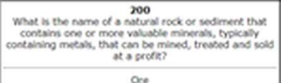 } & 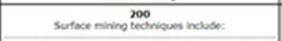 & \multirow{3}{*}{ 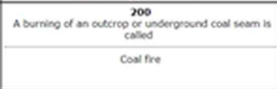 } & \multirow{3}{*}{ moxin cwas } \\
\hline & \multirow[t]{2}{*}{ 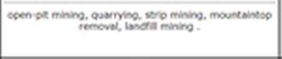 } & & \\
\hline & & & \\
\hline 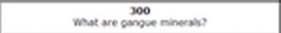 & \multirow{2}{*}{ 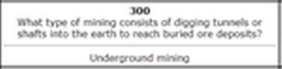 } & 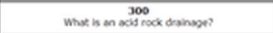 & $\begin{array}{l}300 \\
\text { max } \\
\text { soman? }\end{array}$ \\
\hline 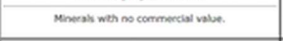 & & 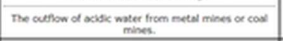 & sole orinem waseer nat \\
\hline What is pliscer secosen? & What is instion lesching? & 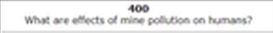 & mat 10050000 \\
\hline 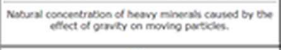 & 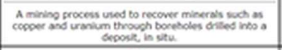 & 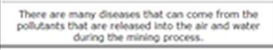 & 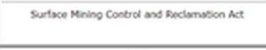 \\
\hline \multirow{2}{*}{ 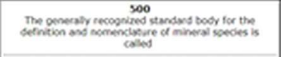 } & \multirow{2}{*}{ 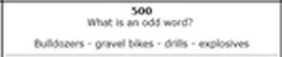 } & $\begin{array}{l}500 \\
\text { maxt are talings? }\end{array}$ & \multirow{3}{*}{ 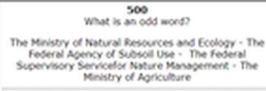 } \\
\hline & & \multirow{3}{*}{ 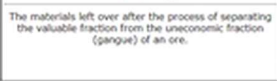 } & \\
\hline \multirow[t]{2}{*}{ 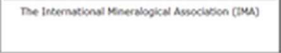 } & \multirow[t]{2}{*}{ grevel baes } & & \\
\hline & & & De Menstor of aptouture \\
\hline
\end{tabular}

Fig. 4. Game content (questions and responses) for mining students.

All these services let teachers and students receive an instant feedback. It is a vital part of formative assessment, which enhances a rise of students' motivation, giving them a possibility to evaluate and control learning by themselves [9]. Furthermore, this function allows a teacher instant detection of knowledge gaps [10], helps to reveal weak points of presenting learning material and correct teaching methods. Due to it, a teacher can reveal what language aspect or material needs additional clarification or more repetition and prepare problem-solving tasks for post-test discussion.

\section{Results and discussion}

The experiment, carried by us in 2019-2021 at Kemerovo State University involved the summative and formative assessment stages. During the summative assessment we revealed motivation reasons among three groups of students (Bachelors of the Slavic language, Bachelors of the Turkic language, Master students of the Slavic language). We hadn't got enough Master students of the Turkic language. At the summative assessment we revealed their motivation reasons (Acquisition of knowledge, Mastering a profession and Getting a diploma) with the questionnaire presented above.

The questionnaire's results must be processed and interpreted in the following way: 
Scale "Acquisition of knowledge"

- 3.6 points are given for agreement ("+") with the statement 4; with the statement 17 - 3.6 points; with the statement $26-2.4$ points;

- for disagreement ("-") with the statement $28-1.2$ points; with the statement $42-1.8$ points.

Maximum is 12.6 points.

Scale "Mastering a profession"

- for agreement with statement 9 - 1 point; with the statement 31 - 2 points; with the statement 33 - 2 points; with the statement 43 - 3 points; with the statement 48 - 1 point and with the statement 49 - 1 point.

The maximum is 10 points.

Scale "Getting a diploma"

- for disagreement with the statement $11-3.5$ points;

- for agreement with the statement $24-2.5$ points; with the statement $35-1.5$ points; with the statement $38-1.5$ points and with the statement $44-1$ point.

The maximum is 10 points.

Statements 5, 13, 30, 39 are neutral to the goals of the questionnaire and are not included in the processing.

The predominance of Acquisition of knowledge and Mastering a profession motivation mean a reasonable professional choice and satisfaction of a student.

We can see from Table 1. that all groups were mostly oriented to acquisition of knowledge (8.6; 9.4 and 6.1 points respectively). Getting a diploma motivation took the second place for the Bachelors and Masters of the Slavic language group (5.6 and 4.1 points respectively), while is the least popular for Bachelors of the Turkic language group. Mastering knowledge motivation was quite unpopular and low. It was the lowest for Bachelors and Master students of the Slavic language group (4.5 and 3.6 points respectively) and a bit higher for the Turkic language group (4.6 points). Thus, we concluded that the group of Master students needs activities to increase interest in professional development

Bachelors of the Turkic language group of KemSU became interested in the research and decided to interview their former classmates that were studying at universities in St. Petersburg (Russia), Osh (Kyrgyzstan), Izmir (Turkey). A total of 154 people took part in the survey. Analyzing the results, we divided them into 1 experimental group (20 Master students) and 2 control groups (70 and 16 Bachelors). Master students of the Slavic language was chosen as the experimental group because of the lowest points of "Mastering a profession" motivation. In general, "Acquisition of knowledge" and "Mastering a profession" motivation should be dominant, but not "Getting a diploma". Bachelors of the Turkic language group of other Russian university and bachelors of the Turkic language group of foreign universities were not our students, so we could not influence on them. But their participation in the survey was rather useful as students of KemSU were able to appreciate the high results of the former classmates' motivation.

Table 1. Results (2019-2020).

\begin{tabular}{|c|c|c|c|c|c|}
\hline $\begin{array}{l}\text { Answer } \\
\text { options }\end{array}$ & $\begin{array}{l}\text { Bachelors of } \\
\text { the Slavic } \\
\text { language } \\
\text { group of the } \\
\text { KemSU } \\
\text { (70 people) }\end{array}$ & $\begin{array}{l}\text { Bachelors of } \\
\text { the Turkic } \\
\text { language } \\
\text { group of the } \\
\text { KemSU (16 } \\
\text { people) }\end{array}$ & $\begin{array}{c}\text { Master } \\
\text { students of } \\
\text { the Slavic } \\
\text { language } \\
\text { group of the } \\
\text { KemSU (20 } \\
\text { people) }\end{array}$ & $\begin{array}{c}\text { Bachelors of } \\
\text { the Turkic } \\
\text { language } \\
\text { group of } \\
\text { another } \\
\text { Russian } \\
\text { university ( } 8 \\
\text { people) }\end{array}$ & $\begin{array}{l}\text { Bachelors of } \\
\text { the Turkic } \\
\text { language } \\
\text { group of } \\
\text { foreign } \\
\text { universities } \\
\text { (40 people) }\end{array}$ \\
\hline
\end{tabular}




\begin{tabular}{|c|c|c|c|c|c|}
\hline $\begin{array}{c}\text { Acquisition of } \\
\text { knowledge }\end{array}$ & 8.6 & 9.4 & 6.1 & 8.5 & 8.5 \\
\hline $\begin{array}{c}\text { Mastering a } \\
\text { profession }\end{array}$ & 4.5 & 4.6 & 3.6 & 6 & 7.1 \\
\hline $\begin{array}{c}\text { Getting a } \\
\text { diploma }\end{array}$ & 5.6 & 4.1 & 4.1 & 4 & 5 \\
\hline
\end{tabular}

At the summative assessment we tested the language level (English) among all students which showed different results. It was the lowest (35\%) among Bachelors of the Turkic language group, which can be explained by a low school level of English and a great difference between Turkic and German language groups. The highest level was among Bachelors of the Slavic language group (74\%), which can be explained a close link to school. All of them had 3 language lessons a week at school and entered professional language smoothly. Meanwhile Master students of the Slavic language group demonstrated rather low language level too (44\%) because of a long gap. Many of them stopped studying English on the second year at University and hence had 2-3 gap year before studying it in Master school.

During the formative assessment we created and integrated interactive tasks, worksheets, online quizzes described above into the ESP lessons of the experimental group to enhance their motivation to profession. The professional vocabulary was taught in various ways in the experimental and control groups. We offered ESP lessons supported with the interactive tasks and quizzes described above for the experimental group and traditional ESP lessons for the control groups. The experimental students were encouraged to work with these services both in the classroom and at home during out-of-class independent work. Students of all groups were supposed to do similar learning activities to build professional thesaurus but presented either in an interactive or traditional way. To assess their learning outcomes, we used quizzes and interview method. Thus, we carried out six offline and online quizzes, a midterm and a final quiz in three groups. All quizzes were created in Factile and were carried as trivia games to encourage revisional discussion of each term topic. All the quizzes were identical for each educational level.

During the formative assessment, we compared the average quiz scores in the experimental (Master students of the Slavic language group), control group 1 (Bachelors of the Slavic language group) and control group 2 (Bachelors of the Turkic language group) (Fig.5).

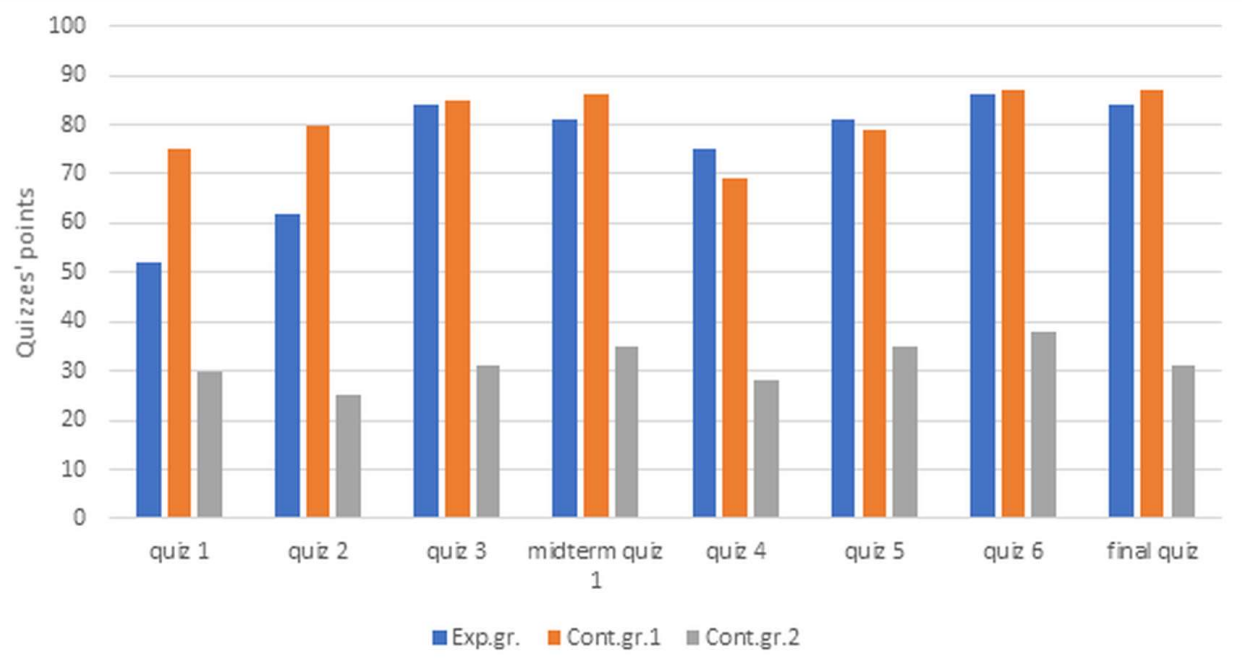


Fig. 5. Average quiz scores of the experimental and control groups in 2019-2020 studying years.

We can see from the Fig. 5 that the learning outcomes of all student groups experienced an upward trend throughout the academic year. They all had some fluctuations, and the level of the experimental group coincided with the control group 1 and outraced the control group 2. We can explain this with a high initial language level of the control group 1 and highly motivational interactive ESP lessons for the experimental group, though their level was lower at the start of the experiment. Thus, we can conclude that ESP lessons supported with interactive educational tasks could increase the learning outcomes of students. Moreover, such high results can be interpreted also by an active post-task/test discussion and lesson design transformation. It was curious to compare these results with our previous experiment, connected with teaching professional vocabulary to students in coal region universities through digital educational tools [11].

Finally, to know students' attitude to online learning activities implemented in ESP lessons we developed the online questionnaire of 10 questions about.

1.How did you adapt to the new conditions of distance learning?

2. Is it convenient for you to study remotely?

3. Evaluate your level of motivation to learn in the distance form.

4. Are you satisfied with the distance learning process?

5. Are you comfortable using online learning activities implemented in ESP lessons?

6. Do you like the hybrid form of education?

7. In what format would you like to continue your further education: full-time, distance learning or hybrid?

8. Which vocabulary learning app has been the most effective for you?

9. Would you like to continue learning through language applications?

10. Has your level of professional motivation increased?

We also decided to check if their motivation reasons had been changed for this period and interviewed them with the same questionnaire again in 2020-2021.

Table 2. Results (2020-2021).

\begin{tabular}{|c|c|c|c|}
\hline Answer options & $\begin{array}{c}\text { Bachelors of the } \\
\text { Slavic language } \\
\text { group of the KemSU } \\
\text { (70 people) }\end{array}$ & $\begin{array}{c}\text { Bachelors of the } \\
\text { Turkic language } \\
\text { group of the KemSU } \\
\text { (16 people) }\end{array}$ & $\begin{array}{c}\text { Master students of } \\
\text { the Slavic language } \\
\text { group of the KemSU } \\
\text { (20 people) }\end{array}$ \\
\hline $\begin{array}{c}\text { Acquisition of } \\
\text { knowledge }\end{array}$ & 8.1 & 7.3 & 6.2 \\
\hline $\begin{array}{c}\text { Mastering a } \\
\text { profession }\end{array}$ & 4.7 & 5.8 & 6.6 \\
\hline Getting a diploma & 4.6 & 4.1 & 2.1 \\
\hline
\end{tabular}

We can see from Table 2, that indicators of "Acquisition of knowledge" and "Mastering a profession" became higher for the Master students of the Slavic language group (6.2 and 6.6 points respectively), and indicator "Getting a diploma" decreased (2.1 points). Conditionally good indicators ("Acquisition of knowledge" and "Mastering a profession") in bachelors of the Slavic language group and bachelors of the Turkic language group also increased $(8.1 ; 7.3$ and $4.7 ; 5.8$ respectively). 


\section{Conclusion}

The data indicate that mining engineering students need better and more effective ways of learning ESP and more professional motivation. Their teachers need to employ more effective teaching methods. To follow new higher educational standard and post-pandemic realia demand about making digital competence and skills the inherent part of education and integrating e-learning and web-services into teaching. Mining engineering students claimed this approach improved their overall satisfaction with ESP study, also they became more interested in their profession because of an innovative way of interaction in classroom formats.

Online learning activities have considerable potential in educational process due to deeper digestion of learning material, instant feedback from students which allows to trace their learning problems (weak points), automatic evaluation of students' responses. All this, combined with traditional training techniques increase students' motivation and satisfaction with ESP learning. It opens great opportunities for education and professional development of a young specialist.

\section{Acknowledgements}

The reported study was funded by RFBR according to the research project № 19-01300805 .

\section{References}

1. O. Kulikova, Vocabulary learning strategies and beliefs about vocabulary learning: a study of beginning university students of Russian in the United States (University of Iowa, Iowa, 2015)

2. O. Greenwald, A. Resenchuk, T. Sergeychick, E3S Web Conf. 105, 04019 (2019)

3. I. Gubanova, A. Shirokolobova, Scientific and technical translation training of nonlinguistic university students in e-learning environment, MATEC Web Conf. 297, 06002 (2019)

4. J. Filgona, J. Sakiyo, D.M. Gwany, A.U. Okoronka, Asian Journal of Education and Social Studies, 10(4), 16-37 (2020)

5. E. Ushioda, Language learning at university: Exploring the role of motivational thinking (University of Hawaii Press, Honolulu, 2001)

6. I. Šimonová, K. Kostolányová, L. Faltýnková, Advances in Intelligent Systems and Computing, 1328, 100 (2021).

7. H. Krishnasamy, A. Samir, Opcion, 35, 132-147 (2019)

8. Yu.G. Odegov, G.G. Rudenko, S.N. Apenko, A.I. Merko, Staff Motivation: Study guide (Publishing house "Alfa-Press", Moscow, 2010)

9. D. Nicol, D. Macfarlane-Dick, Studies in Higher Education, 31:2, 199-218 (2010)

10. T. Talmo, G. Sivertsen Korpås, M. Mellingsæter, E. Einum, Proceedings of the 5th International Conference of Education, Research and Innovation, 19:21, 4540-4545 (2012)

11. A. Perevalova, A. Resenchuk, N. Tunyova, E3S Web Conf. 174, (2020) 04051 